\title{
Review of Fagraea gracilipes complex (Loganiaceae)
}

\author{
Barry J. Conn \& Elizabeth A. Brown
}

\begin{abstract}
Conn, Barry J. \& Brown, Elizabeth A. (National Herbarium of New South Wales, Royal Botanic Gardens, Sydney, NSW, Australia 2000). Review of Fagraea gracilipes complex (Loganiaceae). Telopea 5(2): 363-374. A review of the current circumscription of Fagraea gracilipes has shown that the present broad-species concept does not adequately explain the taxonomic diversity of this group. Fagraea gracilipes is here regarded as an endemic of Fiji, with $F$. cambagei and F. fagraeacea (s. str.) restricted to Australia, F. amabilis, F. sp. (Southern New Guinea) and F. dolichopoda restricted to New Guinea, and F. obtusifolia re-instated for the Solomon Islands.
\end{abstract}

\section{Introduction}

Leenhouts (1962) treated the Fagraea gracilipes complex as a single variable species occurring in New Guinea, the Bismarck Archipelago, the Solomon Islands (including Santa Cruz), Australia and Fiji. He regarded this species as being represented by several variants that, although often locally distinguishable, were not worthy of formal recognition (Leenhouts 1962). However, Smith (1988) suggested 'that nomenclatural recognition at some level may be desirable' (Smith 1988: 41) within the complex. A study of the genus for the 'Flora of Australia' and 'Flora of Papua New Guinea' projects has prompted a re-evaluation of the F. gracilipes complex.

This paper aims to bring the taxonomic problems of this complex to the attention of systematists. The current broad-species concept of this complex has largely hidden the biological reality of the entities within this group. The conclusions presented here must be regarded as tentative since they are based on inadequate data. It is hoped. that plant collectors will take a renewed interest in these taxa and make collections that will help to resolve the remaining taxonomic complexities of this group.

\section{Methods and presentation}

Measurements of the morphological characters and subsequent descriptions were taken from approximately 1100 herbarium specimens (including duplicates) held at A, B (photographs only), BM, BRI, CANB, F, K, LAE, MEL, QRS, UC, US.

The distribution summary and the citation of selected specimens examined are grouped according to various regional subdivisions. The subdivisions used for New Guinea and the Solomon Islands follow Womersley (1978), those for Queensland follow the pastoral divisions as in Contr. Queensland Herbarium 19 (1975) back end-paper. Inflorescence terminology follows Briggs \& Johnson (1979). 


\section{Discussion and taxonomic conclusions}

It has proved extremely difficult to clarify the taxonomic relationships within the Fagraea gracilipes complex because of inadequate herbarium material and field knowledge. Very few additional collections of this complex have been made from New Guinea and the Solomon Islands since Leenhouts' study. Furthermore, much of the herbarium material is inadequate and so cannot even be positively identified to species level. Many specimens are sterile and frequently consist only of shade or juvenile leaves. Fertile material with juvenile leaves is difficult to identify; however, it is usually easier to identify than those that have shade leaves only. The shade leaves of some species are usually large and frequently similar in size to the nonshade leaves of other species. For example, sterile material of $F$. fagraeacea (s. str.) that has only shade leaves is difficult to distinguish from a specimen of $F$. cambagei grown in the sun. Since the fruits are fleshy, it is often difficult to estimate the shape and size of the dried fruits on herbarium specimens. The difficulty is further compounded because much of the fruiting material consists only of immature fruits, even though the collector's notes frequently appear to describe mature fruits. Therefore, there is always some doubt about the size of fresh mature fruits. The 'apparent' overlap of morphological features, as represented by the herbarium material, is probably an artifact of collection.

Fortunately, understanding of the Australian taxa has increased significantly because of the additional herbarium material available and the opportunity for the authors to undertake field studies of the taxa. Likewise, the additional collections from Fiji have made it possible to precisely circumscribe the Fijian populations (Smith 1952, 1988). It is here concluded that the Fagraea gracilipes complex consists of seven taxa that should be recognised as distinct species. Six of these taxa are both ecologically and morphologically sufficiently distinct (although often difficult to assess from herbarium material) to be clearly recognised as separate species. Legitimate names are available for these six species. The seventh taxon ( $F$. sp. (Southern New Guinea)) is not formally described as a distinct species because it is insufficiently well known to evaluate its taxonomic status. Although it is ecologically distinct, it is morphologically similar to F. fagraeacea s. str. (of Australia). Therefore, we have included it in the key to species, but have refrained from formally describing this taxon until more complete collections are available.

Leenhouts' delimitation (Leenhouts 1962) of the complex is similar to ours. Furthermore, he has recognised similar morphological variation within the $F$. gracilipes complex, but he felt that the variation was taxonomically unimportant. However, he differed from us because he included F. dolichopoda in the 'F. elata race' (=F. amabilis). 


\section{Taxonomy}

\section{Key to species}

Note: measurements and shape of leaves refer to mature leaves only.

1 Corolla narrowly funnel-shaped to almost tubular; mouth less than $5 \mathrm{~mm}$ in diameter, sometimes to $5 \mathrm{~mm}$

2 Pistil 25-30 mm long; stigma exserted 5-10 $\mathrm{mm}$ beyond corolla mouth; leaves narrow, 1.8-4.5 mm wide; inflorescence usually 15-30-flowered, rarely as few as 3 - or as many as 50-flowered (Australia, altitude $700-1350 \mathrm{~m}$ )

\section{F. fagraeacea}

$2^{*}$ Pistil 23-25 mm long; stigma exserted 4-5 mm beyond corolla mouth; leaves usually 4.5-7.3 mm wide; inflorescence 9-15(-20)-flowered (New Guinea, from sea level to $70 \mathrm{~m}$ altitude)

6. F. sp. (Southern New Guinea)

$1^{*}$ Corolla distinctly and broadly funnel-shaped in upper half, basally \pm tubular; mouth more than $5 \mathrm{~mm}$ in diameter

3 Peduncle and pedicel slender; inflorescence up to 9-flowered

4 Lamina elliptic to narrowly elliptic, rarely broadly so $15.5-20 \mathrm{~cm}$ long, $2-8.5(-10) \mathrm{cm}$ wide], apex obtuse to acute or shortly acuminate (acumen c. $4 \mathrm{~mm}$ long); veins distinct, usually raised on lower surface; petiole 1.5-5 cm long; inflorescence usually 9-flowered; anthers 3-4 mm long (Fiji, sea level to $500 \mathrm{~m}$ altitude 1. F. gracilipes

$4^{*}$ Lamina narrowly obovate to narrowly elliptic [(5.5-)8.5-12.5 cm long, $2.1-4(-5) \mathrm{cm}$ wide], apex distinctly acuminate to attenuate (acumen 5-12 $\mathrm{mm}$ long), apex rarely obtuse; veins faint or not visible; petiole 1.3 $2.7 \mathrm{~cm}$ long; inflorescence (3-)5-7-flowered; anthers $2.5-3 \mathrm{~mm}$ long (Papua New Guinea, at 700-2300 m altitude)

7. F. dolichopoda

$3^{*}$ Peduncle and pedicel thickened and hence robust; inflorescence variable, usually at least 10-flowered (except inflorescence of $F$. amabilis is (5-)7-15(-20)-flowered)

5 Pistil 23-26 mm long; pistil and anthers not or only just exserted beyond the corolla mouth; inflorescence relatively compact with adjacent peduncles and pedicels not strongly divergent (Australia, sea level to altitudes of $500 \mathrm{~m}$, rarely to $700 \mathrm{~m}$ )

4. F. cambagei

5* Pistil 25-40 mm long; pistil and anthers distinctly exserted (by 5-10 mm) beyond the corolla mouth; inflorescence open with adjacent peduncles and pedicels moderately to strongly divergent

6 Lamina usually broadly elliptic to almost circular, (7-)8.5-11.5 cm wide; inflorescence usually 20-30-flowered, rarely a few as 9-flowered; fruits 1-2(-2.5) cm long; anthers inserted in lower third of corolla tube (Solomon Islands, sea level to $320 \mathrm{~m}$ altitude)

$6^{*}$ Lamina elliptic, rarely slightly obovate or narrowly elliptic, (3.5-)5-8.3 cm wide; inflorescence usually 7-15-flowered, rarely as few as 5- or as many as 20-flowered; fruits 3-3.5(-5) cm long; anthers inserted \pm at middle of corolla tube (New Guinea, at altitudes of $1170-2300 \mathrm{~m}$ ) 
1. Fagraea gracilipes A. Gray, Proc. Amer. Acad. Arts Sc. 4: 323 (1859).

TYPE: Fin: 'Feejee Islands', Capt. Wilkes Herb. U.S. Exploring Expedition s.n., [1840] (holo US 62265; iso GH, K)(refer Smith 1988 for full citation list).

[Fagraea viridiflora Seem. Bonplandia 9: 257 (1861), nomen nudum. Based on Seemann 306, July 1860, Port Kinnaird, Ovalau, Fiji (BM, GH, K).]

Small to medium tree, usually to $15(-25) \mathrm{m}$ high. Leaves with petiole $1.5-5 \mathrm{~cm}$ long; lamina narrowly elliptic to elliptic, rarely broadly so, $5.5-20 \mathrm{~cm}$ long, $2-8.5(-10) \mathrm{cm}$ wide; base usually attenuate, sometimes narrowly acute to broadly cuneate; apex obtuse to acute or shortly acuminate; veins distinct, although sometimes faint; stipules often indistinct, split into 2 small axillary halves, which are partly adnate to petiole. Inflorescences terminal, metabotryoidal, mostly 9-flowered; peduncles and pedicels slender; prophylls inserted c. $1 / 2$ way up pedicels. Caly $x$ campanulate, (2.5-) 3-5 mm long; lobes suborbicular. Corolla cream-coloured, fading to pale yellow or orange-yellow, scented, funnel-shaped (lower half tubular); tube 14-25 mm long; mouth 6-8 mm wide; lobes \pm oblong, 8-10 mm long. Stamens inserted c. $1 / 2$ way up tube, erect; filaments 15-25 mm long; anthers 3-4 mm long, exserted. Pistil 20-30 mm long, exserted 5-10 mm beyond mouth; stigma capitate, entire to faintly bilobed. Fruit broadly ellipsoid-ovoid, $1.5-2.3 \mathrm{~cm}$ long, base of style persistent, hence fruit apically beaked, waxy-white to cream-coloured at maturity; pedicel slender, becoming slightly thicker below fruit, somewhat lengthened; calyx appressed, slightly enlarged.

Distribution: Endemic to Fiji, occurring on Kandavu, Vanua Levu and Viti Levu.

Habitat: Occurs in dry or dense wet forest, in forest patches in grassland; and infrequently on the inner edge of mangrove swamps. Altitude from near sea level to c. $500 \mathrm{~m}$.

NoTEs: The populations of this species are relatively homogenous and have already been recognised as representing F. gracilipes s. str. by Leenhouts (1962) and Smith (1988).

This species is a small to medium, often spreading tree which is morphologically similar to F. cambagei of Australia. The leaves are similar in size and shape, but the petiole of $F$. gracilipes is mostly longer than found in $F$. cambagei $(1.5-5 \mathrm{~cm}$ long cf. 2-3.5 cm long, respectively). The inflorescence is mostly 9-flowered, whereas, in F. cambagei it is up to about 30 -flowered. The peduncles and pedicels are slender in $F$. gracilipes, whereas they are robust in $F$. cambagei. The flowers are similar in both species, but the corolla tube of $F$. gracilipes is mostly shorter than found in $F$. cambagei (14-25 mm long of. 20-31 mm long, respectively). The stamens are inserted about half-way up the corolla tube in $F$. gracilipes, whereas they are inserted in the upper half in F. cambagei. The pistil is slightly longer in F. gracilipes than in F. cambagei (20-30 mm long cf. 23-26 mm long, respectively), but more importantly, the pistil is exserted 5-10 mm beyond the corolla mouth in F. gracilipes, whereas it is not or only just exserted in $F$. cambagei. The pedicel remains slender in $F$. gracilipes, whereas it is robust in F. cambagei. Ecologically, Fagraea gracilipes prefers drier sites than F. cambagei, infrequently occurring on the inner edge of mangroves (a common site for F. cambagei).

BARK \& wooD: Bark not known; wood regarded as valuable because the timber is hard, straight and durable.

Selected SPECIMENS (35 examined): FiJi: VITI Levu: Serua (vicinity of Ngaloa), Degener 15101, 22 Apr-7 May 1941 (UC 016188, US 1943939), Smith 9334, 26 Nov-26 Dec 1953 (UC 1344684, US 2191810); Serua (vicinity of Ndeumba), McKee 2779, 17 Jul 1955 (US 2192456). Vanua Levu: 
2. Fagraea obtusifolia Merr. \& Perry, J. Arnold Arbor. 23: 415 (1942).

TYPE: SOLOMON IsLANDS: YSABel [Santa Isabel]: Tataba, Brass 3444, 5 Jan 1933 (holo A; iso BRI 317361).

Tree 7-27 m high. Leaves with petiole $2.5-5 \mathrm{~cm}$ long; lamina broadly elliptic (almost circular) to elliptic or slightly obovate, $10.3-20 \mathrm{~cm}$ long, (7-)8.5-11.5 cm wide; base cuneate to rounded and abruptly cuneate; apex mostly rounded, sometimes obtuse to shortly acuminate (acumen $2-5 \mathrm{~mm}$ long), rarely retuse; midrib distinctly raised on lower surface; veins distinct; stipules indistinct, split into 2 small axillary halves that are partly adnate to petiole. Inflorescences terminal, metabotryoidal, open but appearing crowded when many-flowered, with $a_{2}$ axes moderately divergent from $a_{1}$ axis, (9-)20-30-flowered, peduncles and pedicels moderately robust; prophylls inserted $1 / 3-1 / 2$ way up pedicel, broadly triangular, with apex obtuse. Calyx $3-5 \mathrm{~mm}$ long; lobes suborbicular. Corolla white, often with a yellowish or greenish tinge, distinctly funnel-shaped distally; tube 20-26 mm long; mouth 9-11 mm wide; lobes oblong, c. $10 \mathrm{~mm}$ long, c. $10 \mathrm{~mm}$ wide. Stamens inserted in lower $1 / 3$ of tube, distinctly exserted; anthers c. $3 \mathrm{~mm}$ long. Pistil $30-40 \mathrm{~mm}$ long, distinctly exserted beyond mouth; stigma capitate, entire. Fruit ovoid, 1-2(-2.5) cm long; mature fruits white; pedicel only slightly thickened and lengthened; calyx slightly enlarged.

Distribution: Endemic to the Solomon Islands (including Santa Cruz).

HABITAT: Occurs, on well-drained sites, on slopes and ridges, in primary forests, usually in deep red clay-rich soils. Once recorded from mangrove swamps (Corner 2738). Altitude sea level to $c .320 \mathrm{~m}$.

Notes: This species is morphologically very homogeneous. It usually has broadly elliptic to almost orbicular leaves, sometimes slightly obovate. The leaf apex is either very shortly acuminate, rounded, or sometimes retuse. The venation of the leaves is distinct, with raised veins on the lower surface. Morphologically it is somewhat distant from the other species in the complex; however, it appears to have its closest affinities with $F$. gracilipes. It differs from $F$. gracilipes by having broadly obovate to orbicular leaves whereas the former has narrowly elliptic to elliptic leaves (length to width ratio $1.2-1.7$ and mostly $2.4-2.8$, respectively). The leaves of $F$. gracilipes usually have attenuate bases whereas those of $F$. obtusifolia are rounded to cuneate. The inflorescences of $F$. gracilipes are few-flowered (usually 9-flowered), with slender peduncles and pedicels, whereas those of $F$. obtusifolia are usually 20-30-flowered, although sometimes as few as 9-flowered and have robust peduncles and pedicels.

BARK AND WOOD: Outer bark dark to light brown, coarsely fissured; inner bark creamcoloured with close orange circular flecks; outer wood light brown to reddish or pink-brown, hard.

SELECTED SPECIMENS (24 examined): SOLOMON ISLANDS: ChOISEul: coast opposite Bembalama Island, Whitmore BSIP 4024, 3 Mar 1964 (LAE 62114). New GEORGIA: Vaimbu River, Whitmore's collectors BSIP 3172, 2 Apr 1964 (LAE 63742). SANTA IsABEL: Turungurungu I. (San Jorge), Corner RSS 2738, 25 Sep 1965 (CANB 183743). GuAdalCANAL: Bilikovu River, Wanderer Bay, Gaifu et al. BSIP 9136, 3 Apr 1968 (LAE 101153). MalaiTA (Small Malaita): E of Pululaha, Gaifu et al. BSIP 16295, 18 Aug 1969 (LAE 147164). SANTA CRUZ: Vanikoro: south coast at Emwa, Whitmore BSIP 1685, 8 Apr 1963 (LAE 55901). 
3. Fagraea amabilis S. Moore, J. Bot. 61: suppl. 36 (1923).

Type: Papua New Guinea: Central: Sogeri region, Forbes 420, anno 1885-1886 (holo BM - photo seen; iso LAE 236957).

F. elata Merr. \& Perry, J. Arnold Arbor. 23: 413 (1942). Type: Western New Guinea: JAYAPURA: Bernhard Camp, Idenburg River, Brass 11975 \& Versteegh, Jan 1939 (holo A, n.v.; iso LAE 6260).

Tree 10-28 m high. Leaves with petiole (0.7-)1.5-4 cm long; lamina elliptic to slightly obovate, rarely narrowly elliptic, $7.8-15(-18) \mathrm{cm}$ long, $(3.5-) 5-8.3 \mathrm{~cm}$ wide; base cuneate, occasionally somewhat abruptly so; apex bluntly acuminate to rounded (acumen c. $4 \mathrm{~mm}$ long), rarely retuse; midrib distinctly raised on lower surface; veins distinct; stipules indistinct, split into 2 small axillary halves that are partly adnate to petiole. Inflorescences terminal, metabotryoidal, crowded, with $\mathrm{a}_{2}$ axes short and moderately divergent from $a_{1}$ axis, (5-)7-15(-20)-flowered; peduncles and pedicels moderately robust; prophylls inserted $1 / 2$ way up pedicel, broadly triangular, with apex \pm acute. Calyx c. $5 \mathrm{~mm}$ long; lobes oblong. Corolla white, often with a yellowish or greenish tinge, funnel-shaped; tube c. $25 \mathrm{~mm}$ long, thick and fleshy; mouth c. 12 mm wide; lobes oblong, c. $12 \mathrm{~mm}$ long, c. $11 \mathrm{~mm}$ wide, with margin entire, membranous, often becoming ragged. Stamens inserted c. $1 / 2$ way up tube, distinctly exserted; anthers c. $3 \mathrm{~mm}$ long. Pistil c. $30 \mathrm{~mm}$ long, distinctly exserted beyond mouth; stigma capitate, entire. Fruit ovoid, 3-3.5(-5) cm long, with prominent beak (beak c. $8 \mathrm{~mm}$ long); mature fruits orange; pedicel thickened below calyx, not or only slightly lengthened; calyx slightly enlarged.

Distribution: Collected from the Jayapura, West Sepik, Western Highlands and Southern Highlands districts of New Guinea.

HABITAT: Occurs in montane to lower montane communities, usually in Nothofagusdominated forest, at $1170-2300 \mathrm{~m}$ altitude.

Notes: This species is morphologically similar to $F$. dolichopoda, which also occurs at high altitudes in Papua New Guinea. The floral characteristics of $F$. amabilis and $F$. dolichopoda are similar, with both having relatively large flowers. However, they differ by several features. The leaves of $F$. amabilis are elliptic to slightly obovate, whereas $F$. dolichopoda has narrowly obovate to narrowly elliptic leaves ((3.5-)5-8.3 cm wide and $2.1-4(-5) \mathrm{cm}$ wide, respectively). There is a tendency for $F$. amabilis to have slightly more flowers per inflorescence than $F$. dolichopoda (respectively, (5-)715(-20)-flowered and (3-)5-7-flowered). Fagraea amabilis has larger fruits $(3-3.5 \mathrm{~cm}$ long, rarely to $5 \mathrm{~cm}$ ) compared to those of $F$. dolichopoda, which appear to be only c. $1.5 \mathrm{~cm}$ long.

BARK \& WOOD: Outer bark grey-brown to cream-brown, smooth; inner bark pale brown to light orange; wood straw-coloured to pinkish, hard to very hard.

Selected specimens (10 examined): New Guinea: Jayapura: Ifar-Ormoe, Cycloop Mountains, van Royen E Sleumer 6057, 28 Jun 1961 (BRI 102249, LAE 49874). WEST SEPIK: eastern ridge of Sumset (Mt Hunstein), Hoogland \& Craven 11.074, 18 Aug 1966 (BRI 102350, LAE 143891); Untembil, near Telefomin, Henty NGF 20838, 9 Jan 1965 (BRI 102250, CANB 194566, LAE 96726, NSW). Western Highlands: Pokaris, near Kompiam, Flenley ANU 2882, 15 Jun 1965 (LAE 77252). Southern Highlands: near Ebenda, Anga Valley, Schodde 1631, 27 Jul 1961 (CANB 106499, LAE 57025). CENTRAL: Boridi, Carr 13361, 24 Sep 1935 (CANB 48649, LAE 69946).

Collections from the Southern Highlands district of New Guinea, particularly those from Mt Giluwe were previously regarded as F. gracilipes (s. lat.) (Leenhouts, determinavit slips). These specimens tend to have narrower leaves than those of typical F. amabilis and are here regarded as F. ceilanica Thunb. (cited below). 
Specimens examined: New Guinea: Southern Highlands: Iaro Logging Area, SE slopes of Mt Giluwe, Clunie \& Katik LAE 63299, 13 Feb 1976 (BRI 371271, NSW, QRS 8472); N of Onim Hill, SE slope of Mt Giluwe, Croft et al. LAE 60811, 28 Dec 1973 (BRI 354451, NSW); 0.5 mile W of Iaro Bridge, SE slopes of Mt Giluwe, Croft et al. LAE 60629, 23 Dec 1973 (BRI 354452, NSW, QRS 37805).

\section{Fagraea cambagei Domin, Bibl. Bot. 89(v): 1071 [517] (1929).}

TYPE: Australia: North Queeensland, Harvey's Creek, Domin s.n.; (holo PR n.v.).

Small to medium tree, 5-20 m high. Leaves with petiole $2-3.5 \mathrm{~cm}$ long; lamina elliptic to obovate, 7-23 cm long, (4.5-)7-9 cm wide; base cuneate to attenuate; apex obtuse or shortly acuminate (acumen 4-7 mm long); midrib distinctly raised on lower surface; veins usually distinct although sometimes faint, rarely not visible; stipules often indistinct, split into 2 small axillary halves which are partly adnate to petiole. Inflorescences terminal, metabotryoidal, compact with $\mathrm{a}_{2}$ axes only slightly diverging from $\mathrm{a}_{1}$ axis, up to $\mathrm{c}$. 30-flowered, peduncles and pedicels robust; prophylls inserted c. $1 / 2$ way up pedicel, broadly deltoid to ovate, with apex acute. Calyx 3-5 mm long; lobes suborbicular. Corolla cream-coloured, conspicuously and sweetly fragrant, funnelshaped (narrowly tubular in basal half); tube 20-31 mm long; mouth 8-12 mm wide; lobes oblong, 9-14 mm long, 4-9 mm wide. Stamens inserted in upper $1 / 2$ of tube, not or just exserted; anthers 3.5-4 mm long. Pistil 23-26 mm long, not or only just exserted beyond mouth; stigma subovoid to capitate, entire to slightly bilobed. Fruit globular to ellipsoid, $1.6-3 \mathrm{~cm}$ long, 1-1.9 cm wide; with mature epidermis red, bright pink or white, flesh and pulp white; pedicel robust, becoming thicker immediately below fruit, somewhat lengthened; calyx slightly enlarged.

\section{Distribution: Endemic to North Queensland (Cook district), Australia.}

HABITAT: Occurs as an understorey tree of coastal or near-coastal closed rainforest communities, usually in temporarily inundated or swampy soils, typically behind mangroves and on the low-lying areas of the lower reaches of creeks. Altitude sea level to $500 \mathrm{~m}$, rarely to $700 \mathrm{~m}$.

Notes: This species has close affinities with F. gracilipes (q.v.). This is one of two species that occurs in Australia. Fagraea cambagei is a coastal to near-coastal, riparian species that occurs at low altitudes (sea level to $500 \mathrm{~m}$, rarely to $700 \mathrm{~m}$ ), whereas the other Australian species ( $F$. fagraeacea s. str.) occurs in rocky areas at higher altitudes $(700-1350 \mathrm{~m}$ ). The leaves of $F$. cambagei have petioles $20-35 \mathrm{~mm}$ long ( $F$. fagraeacea has petioles (5-)10-27 mm long). The leaf lamina of F. cambagei is elliptic to obovate and 7-23 x (4.5-)7-9 cm (F. fagraeacea usually has elliptic, sometimes ovate or slightly obovate leaves, $5-10(-12) \times 1.8-4.5 \mathrm{~cm})$. The midrib in $F$. cambagei is distinctly raised on the lower surface and the veins are usually distinct, whereas the midrib is more or less raised on the lower surface of $F$. fagraeacea and the veins are usually indistinct or not visible. Although both species have metabotryoidal inflorescences, those of F. cambagei are compact with the $a_{2}$ axes only slightly divergent from the $a_{1}$ axis, whereas the inflorescence of $F$. fagraeacea is open with the $a_{2}$ axes strongly diverging from $a_{1}$ axis. The peduncles and pedicels of the former species are robust whereas those of the latter are slender. Although there is considerable overlap in the number of flowers per inflorescence in each species, F. fagraeacea usually has more. Fagraea cambagei has larger flowers than $F$. fagraeacea (calyx 3-5 mm long and 1.5-3(-4) $\mathrm{mm}$ long, respectively; corolla tube $20-31 \mathrm{~mm}$ long and 7-21 mm long, respectively, with corolla mouth 8-12 mm wide versus (3-)5-8 mm wide; corolla lobes 9-14 $\mathrm{mm}$ long and (3-)6-8 mm long, respectively). The fruits of $F$. cambagei are larger than those of F. fagraeacea $(1.6-3 \times 1-1.9 \mathrm{~cm}$ and $0.6-1.5 \times 0.4-1.2 \mathrm{~cm}$, respectively). 
The whole fruits of this species are eaten by cassowaries, whereas the seeds are eaten by other birds and rodents, particularly Uromys caudimaculatus (White-tailed Rat)(Irvine, pers. comm.), that characteristically leave the white pulp largely uneaten.

SEEDLINGS: Germination is phanerocotylar (Hyland 7037 - QRS 37837). Three month old seedlings have broadly ovate leaves (1-2 cm long, 1-1.6 cm wide) with leaf-base cordate to broadly cuneate (Hyland 7037 - QRS 37837). One year old seedlings have elliptic to obovate leaves (lamina 11-17 cm long, 4.5-6 cm wide; Hyland 7037 - QRS 37839). Older seedlings not known.

BARK \& WOOD: Outer bark flaky (but segments hard and not detachable) to slightly fissured; subrhytidome green to yellow or brown/cream-coloured; outer blaze creamcoloured to yellow, fibrous; inner blaze cream-coloured to yellow, fibrous, with dark yellow to orange-coloured short vertical stripes; wood yellowish, hard and heavy.

Selected specimens (25 examined): QueEnsland: Cook: State Forest Reserve 143, Little Mossman Logging Area, Gray 951, 27 Mar 1978 (QRS 23403); Gray 3352 (QRS 76102, 76103); Portion 202, Parish of Alexandra, Gray 5167, 30 Jan 1990 (QRS 93032, 93033); Noah Creek, [Daintree National Park], Hyland 1059 RFK, 10 Oct 1967 (QRS 51417-51419); Portion 62, Noah Creek, Hyland 7037, 7 Nov 1973 (QRS 37834-37839); Thornton Beach, Hyland 13431, 15 Dec 1987 (QRS 86517, 86518); near bank of Flin Creek, SW of The Pinnacle, 8 km NE of Julatten, Moriarty 2200, 17 Jan 1977 (BRI 234252; QRS 3135); $2 \mathrm{~km}$ SW of the Pinnacle, c. $13 \mathrm{~km}$ SSE of Mossman, Moriarty 2323, 8 Jun 1978 (QRS 35921); State Forest Reserve 755, Douglas Creek, via the Palmerston Highway, Unwin 607, 28 Jun 1978 (QRS 32400); Oliver Creek, a tributary of Noah Creek, [Daintree National Park], Webb \& Tracey 11596, May 1972 (BRI 292486, CANB 338289, QRS 77615).

\section{Fagraea fagraeacea (F. Muell.) Druce, Rep. Exch. Club Brit. Is. 1916: 623 (1917).}

BAsionYM: Gardneria fagraeacea F. Muell., Fragm. 6: 130 (1868). HoMOTYPIC SYNONYM: Fagraea muelleri Benth., Fl. Austral. 4: 368 (1869), nom. illeg.

Lectotype (here chosen): 'Sea View Range' [in Dallachy's hand], Dallachy s.n., 30 May 1865 (MEL 1610794). Other type material: 'Rockingham's Bay' [possibly in Mueller's hand], Dallachy s.n. (MEL 1610793). [Refer typification notes below.]

Shrub less than $3 \mathrm{~m}$ high, or small to medium tree (3-)5-20 m high. Leaves with petiole (0.5-)1-2.7 cm long; lamina usually elliptic, sometimes ovate or slightly obovate, 5-10(-12) cm long, 1.8-4.5 cm wide; base cuneate; apex obtuse or shortly acuminate (acumen 3-10 mm long); midrib slightly raised on lower surface; veins indistinct or not visible; stipules often indistinct, split into 2 small axillary halves which are partly adnate to petiole. Inflorescences terminal, metabotryoidal, open with $\mathrm{a}_{2}$ axes strongly diverging from $\mathrm{a}_{1}$ axis, (3-)15-30(-50)-flowered; peduncles and pedicels slender; prophylls inserted from just below calyx to $1 / 2$ way up pedicel, broadly triangular to ovate, with apex acute. Calyx 1.5-3(-4) mm long; lobes suborbicular. Corolla cream-coloured, conspicuously fragrant, narrowly funnel-shaped; tube 7-10 (-20) $\mathrm{mm}$ long; mouth (3-)4-5 mm wide; lobes oblong, (3-)6-8 mm long, (2-)4-5 mm wide. Stamens inserted in upper $1 / 2$ of tube, long-exserted; anthers $2-2.5 \mathrm{~mm}$ long. Pistil $25-30 \mathrm{~mm}$ long, exserted 5-10 $\mathrm{mm}$ beyond mouth; stigma subovoid to capitate, entire to slightly bilobed. Fruit globular to slightly ellipsoid, $0.6-1.5 \mathrm{~cm}$ long, $0.4-1.2$ $\mathrm{cm}$ wide; mature fruit with epidermis red, bright pink or white, frequently white with a faint pink tinge, flesh and pulp white; pedicel slender, becoming thicker immediately below fruit, somewhat lengthened; calyx slightly enlarged.

Distribution: Endemic to North Queensland (Cook and North Kennedy districts), Australia. The type (from the Sea View Range) and Conn 3656 (Brown \& Doust)(from Mt Spec National Park, near Paluma) appear to represent disjunct populations. 
Additional collecting in the Cardwell Range to Mt Spec National Park area is required to verify the distribution of this species in the region.

HABITAT: Occurs in rocky (granite) mountainous rainforest communities. Altitude 700$1350 \mathrm{~m}$.

Notes: This species is morphologically similar to F. sp. (Southern New Guinea) (refer to 'Key to species' for the differences between the two taxa). The flowers of this species, particularly the corolla tube, are usually shorter than those of the $F$. sp. 'Southern New Guinea' (namely, corolla tube 7-10(-20) $\mathrm{mm}$ long, 15-20 mm long respectively).

Differences between this species and the other Australian species ( $F$. cambagei) are discussed under the latter species. Juvenile leaves of this species are superficially similar to the mature leaves of $F$. cambagei. Therefore sterile material is often difficult to identify with certainty. The juvenile leaves of $F$. fagraeacea tend to have a slightly obovate lamina, $15-20 \mathrm{~cm}$ long, 4.5-6 cm wide.

TYPIFICATION: The locality of the type material as cited in the protologue (namely, 'In silvis ad sinum Rockingham Bay', Mueller 1868: 130) appears to be a generalised locality that applies to several of Dallachy's collections from this region. There are two Dallachy collections of this taxon (both at MEL) from the Rockingham Bay region. One collection (herbarium sheet MEL 1610794) cites 'Sea View Range' (in Dallachy's hand), as the collecting locality, whereas the other (MEL 1610793) has the more general citation: 'Rockingham's Bay' (possibly in Mueller's hand). Both are regarded as type material, but the herbarium sheet with the more precise locality in Dallachy's hand is here chosen as the lectotype.

SEEDLINGs: Germination not known. Two to three month old seedlings have broadly ovate leaves $(1 \mathrm{~cm}$ long, $1 \mathrm{~cm}$ wide) with leaf-base cordate (Hyland 11455 - QRS 68068,68905 ). One year old seedlings have elliptic to obovate leaves (lamina $5-7 \mathrm{~cm}$ long, 1.7-2.5 cm wide; $Q R S 72814,73175)$. Two year old seedlings have leaves that are slightly obovate, $10.5-12.2 \mathrm{~cm}$ long, $4-4.5 \mathrm{~cm}$ wide (QRS 37842).

BARK \& wOOD: Outer bark grey to grey-brown, more or less fissured, flaky or fluted, lenticels inconspicuous; subrhytidome green to yellow or brown/cream-coloured; outer blaze cream-coloured to yellow, fibrous; inner blaze cream-coloured to yellow, fibrous, with brown or dark cream-coloured short vertical stripes; wood yellowish, hard and heavy.

SelECTED SPECIMENS (46 examined): QueENSLAND: Cook: Elick 106 (QRS 96622, 96623); State Forest Reserve 185, [Mt Haigl, Haig Logging Area, Gray 2353, 6 Jan 1982 (QRS 67409, 68905, 73175); State Forest Reserve 194, [c. $6 \mathrm{~km}$ WSW of Atherton]: Hyland 6688, 2 Mar 1973 (BRI 115301, CANB 261419, QRS 37846-37848); Hyland 7867, 22 Nov 1974 (QRS 19573, 19574); Hyland 11455 (QRS 66972, 66973, 68068, 72814); Irvine 619, 20 Aug 1973 (QRS 37844); Irvine 626, 20 Aug 1973 (BRI 115024, CANB 257082, QRS 37840-37842); Moriarty 1999, 15 Mar 1976 (BRI 234253, CANB 296526, QRS 37825, 37826); State Forest Reserve 143, Mt Lewis, North Mary Logging Area, EP/ 18, Sanderson 542, 12 Nov 1973 (QRS 37843); State Forest Reserve 185, Mt Haig, Stocker 764, 9 Aug 1971 (BRI 102182, CANB 412109, QRS 37850). North Kennedy: $1 \mathrm{~km}$ (by road) E of Paluma, Mt Spec National Park, Conn 3656 (Brown \& Doust), 8 June 1992 (NSW 256625).

SELECTED SPECIMENS EXAMINED WITH JUVENILE LEAVES: State Forest Reserve 194, [c. $6 \mathrm{~km}$ WSW of Atherton], EP/18, Risley 251, 10 Jan 1978 (QRS 19145); State Forest Reserve 143, Mt Lewis, North Mary Logging Area, EP/18, Sanderson 492 (QRS 37845); Garrawalt, Burgoo Logging Area, EP/19, Sanderson 671, 3 Jul 1975 (QRS 37831, 37832); Emerald Logging Area, Sanderson 1298, 22 Nov 1977 (QRS 17397); State Forest Reserve 194, [c. 6 km WSW of Athertonl, Whiffin 609, 17 Mar 1973 (QRS 37824). 
6. Fagraea sp. (Southern New Guinea) 'F. muelleri race' sensu Leenhouts (1962), non Benth. (1869).

Small to medium tree, 5-20 m. high. Leaves with petiole $(1.6-) 2-2.6(-3.5) \mathrm{cm}$ long; lamina elliptic to obovate, sometimes narrowly so, $8.4-16.8 \mathrm{~cm}$ long, (3.6-)4.5-7.3 cm wide; base attenuate to cuneate; apex usually shortly acuminate (acumen 3-5 mm long), occasionally obtuse; midrib slightly raised on lower surface; veins faint to indistinct; stipules often indistinct, split into 2 small axillary halves, that are partly adnate to petiole. Inflorescences terminal, metabotryoidal, open with $\mathrm{a}_{2}$ axes strongly diverging from $a_{1}$ axis, 9-15(-20)-flowered; peduncles and pedicels slender; prophylls usually inserted from just below calyx to $1 / 2$ way up pedicel (rarely on lower $1 / 2$ ), broadly triangular to ovate, with apex acute. Calyx $2.5-3.5 \mathrm{~mm}$ long; lobes suborbicular. Corolla white to cream-coloured, turning yellow with age, narrowly funnel-shaped; tube 15-20 mm long; mouth 4-5 mm wide; lobes \pm oblong, 4-7 $\mathrm{mm}$ long, 3-4 mm wide. Stamens inserted near mid-point of tube, just to distinctly exserted; anthers c. $2 \mathrm{~mm}$ long. Pistil 23-25 mm long, exserted 4-5 mm beyond mouth; stigma capitate, entire or faintly bilobed. Fruit globular $1.2-1.4 \mathrm{~cm}$ diameter, or ellipsoid and c. $1.8 \mathrm{~cm}$ long; colour of mature fruit white, once recorded as orange (McVeagh NGF 8282); pedicel slender, not or only slightly lengthened; calyx not or only slightly enlarged.

Distribution: Endemic to New Guinea; recorded from the Morehead-Weam and Oriomo areas of the Western district and from near Port Moresby in the Central district.

HAвітAт: Occurs in gallery woodlands and forests, sometimes in more open forests, frequently inundated during the wet season, at low altitudes (from 25 to $70 \mathrm{~m}$ ).

Nores: The lack of good herbarium collections and adequate field observations make it impossible to fully evaluate the taxonomic status of this taxon. From herbarium material, Fagraea fagraeacea s. str. (as represented in Australia) is morphologically similar to what is here referred to as $F$. sp. (Southern New Guinea). The differences, as summarised in the 'Key to species', appear to be trivial and it is suspected that they might not be maintained by additional collections. However, the habitat of each is sufficiently distinct to suggest that specimens from lowland gallery woodlands and forests that are frequently inundated and those from rocky mountainous rainforest communities (at 700-1350 m altitude) probably represent separate species. Additional collections and ecological observations are required so that their features can be more precisely defined.

BARK AND WOOD: Outer bark light to dark grey, irregularly vertically fissured or cracked into long rectangular flakes; inner bark cream- to straw-coloured; blaze cream- to straw-coloured, streaked or speckled with amber, aromatic (smelling like over-ripe apples - Pullen 7194); wood moderately hard and dense, yellowish to toffee-coloured; heartwood turning pink when cut.

Selected specimens examined (10 seen): New Guinea: Digul: Along river Digoel, near Koeweh, Versteegh BW 4835, 15 Nov 1957 (LAE 49237); WeStern: c. 2 miles SE of Morehead Patrol Post, Pullen 7194, 29 Aug 1967 (BRI, CANB, LAE 114637, US 2916283); Morehead, Henty \& Foreman NGF 49307, 8 Nov 1972 (CANB 304584, LAE 203400, NSW, US 3001386); Upper Oriomo River, McVeagh NGF 8282, 26 May 1960 (CANB 99523); CENTRAL: Port Moresby subdistrict, Kairo NGF 30840, 19 Aug 1967 (LAE 100577). 


\section{Fagraea dolichopoda Gilg \& Bened., Bot. Jahrb. 54: 196 (1916).}

Type: New Guinea: West SePIK: Felsspitze, Ledermann 12859 [8 Jul-29 Aug 1913] (holo B - photo seen).

Small to medium tree, $2.5-10(-25) \mathrm{m}$ high, once recorded as epiphyte (Craven $\mathcal{E}$ Schodde 1262). Leaves with petiole $1.3-2.7 \mathrm{~cm}$ long; lamina narrowly obovate to narrowly elliptic, (5.5-)8.5-12.5 cm long, $2.1-4(-5) \mathrm{cm}$ wide; base attenuate to cuneate; apex usually distinctly acuminate to attenuate (acumen 5-12 $\mathrm{mm}$ long), rarely obtuse; midrib slightly raised on lower surface; veins faint or not visible; stipules often indistinct, split into 2 small axillary halves which are partly adnate to petiole. Inflorescences terminal, metabotryoidal, open with $a_{2}$ axes strongly diverging from $a_{1}$ axis, (3-)5-7flowered; peduncles and pedicels slender; prophylls inserted on upper $1 / 4$ of pedicel, broadly triangular to ovate, with apex acute. Calyx 4-5 mm long; lobes suborbicular. Corolla white to cream-coloured or somewhat yellowish, often with green tinge, fragrant, funnel-shaped to almost campanulate in distal half; tube (20-)25-27 mm long; mouth 10-13 mm wide; lobes \pm oblong, (7-)9-10.5 mm long, (5-)7-10 mm wide. Stamens inserted just below mid-point of tube, long-exserted; anthers $2.5-3 \mathrm{~mm}$ long. Pistil 32-35 mm long, exserted c. $10 \mathrm{~mm}$ beyond mouth; stigma capitate, entire. Fruit ovoid, c. $1.5 \mathrm{~cm}$ long (immature), white; pedicel slender, becoming slightly thicker immediately below fruit, slightly lengthened; calyx slightly enlarged.

Distribution: Endemic to New Guinea (including Bismarck Archipelago); recorded from the West Sepik, Morobe, Milne Bay, Papuan Islands and New Ireland districts.

HaвiтAт: Occurs in Nothofagus-dominated moss and montane forests, at 700-2300 m altitude.

Notes: This species has close affinities with F. amabilis (q.v.).

The identity of Vinas LAE 59932 is uncertain; however, it is probably a broad-leaved variant of $F$. dolichopoda.

BARK \& WOOD: Outer bark is brown to light grey or cream-coloured, with irregular vertical ridges; inner bark straw-coloured, brittle and fibrous; wood dark strawcoloured to white.

Selected Specimens (13 examined): New Guinea: West SepiK: Prospect Creek near Frieda River, Telefomin subdistrict, Henty \& Foreman NGF 42592, 24 Jun 1969 (BRI, CANB 206703, LAE 112983, NSW). Morobe: near Wengomanga, via Oiwa, Aseki Patrol Area, Craven \& Schodde 1262, 11 Apr 1964 (CANB 199972); Spreader Divide, between Aseki and Menyamya, Streimann \& Kairo NGF 42408, 19 Nov 1970 (BRI, CANB 223949, LAE 126354, K); Basaeng Ridge, track to Moraegoe, Vinas LAE 59932, 10 Oct 1977 (BRI, CANB 412095, LAE 236274, NSW). MilNe BAY: S slope of Mt Rumabubu, Benjamin LAE 67865, 3 Dec 1977 (BRI, CANB 411982, LAE 238262, NSW, QRS 60340, US 2893920); N slopes of Mt Dayman, Brass 23034, 22 Jun 1953 (CANB 124994, LAE 13187, US 2496142). PAPUAN IsLANDS: Fergusson I., mountains between Agamoia and Ailuluai, Brass 26075, 7 Jun 1956 (CANB 56210, LAE 24029). New IrelaNd: 'Bismarck Archipelago' [?Mussau Island], Dissing \& Sandermann 2298, Apr 1962 (LAE 222758).

\section{Acknowledgements}

We wish to thank the curators and staff of the herbaria who allowed us to use the facilities of their institution and/or made available loans of herbarium material. Information on type material held at B, BM and $\mathrm{K}$ was provided by Dr Paul Hiepko (B) and Mr Andrew Doust (NSW). This study was generously supported by an Australian Biological Resources Study Grant. 


\section{References}

Briggs, B.G. \& Johnson, L.A.S. (1979) Evolution in the Myrtaceae - Evidence from inflorescence structure. Proc. Linn. Soc. New South Wales 102: 157-256.

Leenhouts, P.W. (1962) Notes on some species of Fagraea Thunb. Bull. Jard. Bot. Bruxelles 32: 418-458.

Leenhouts, P.W. (1963) Loganiaceae. Fl. Males. ser. I, 6: 293-387.

Smith, A.C. (1952) Loganiaceae, in Studies of Pacific Island Plants, XI. J. Arnold Arbor. 33: 113.

Smith, A.C. (1988) Loganiaceae, in Flora Vitiensis Nova (Pacific Trop. Bot. Garden: Hawaii), vol. 4, pp. 5-43.

Womersley, J.S. (1978) Handbooks of the Fl. Papua New Guinea, vol. 1 (Melbourne Univ. Press: Carlton).

Manuscript received 2 November 1992

Manuscript accepted 10 February 1993 